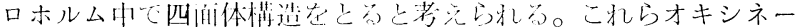

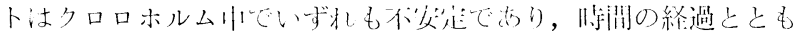

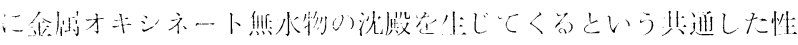

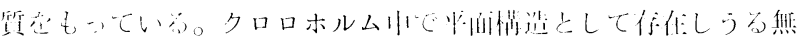

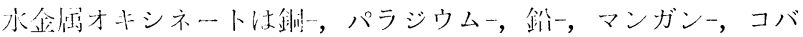

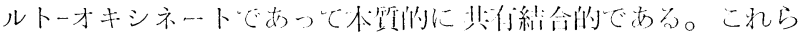

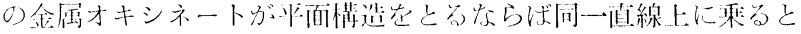
考えら机るが，このらちコバルトー，マンガンーオキシネートは平

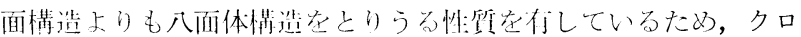
ロホルムの影锌を受けてさらに分離して别の直線上に乘るのであ ろう。东た同一直線上:でも共詴絬合州:の強い金属のオキシネート

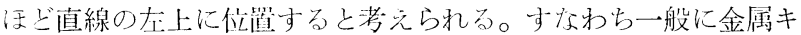
レートの安定度が其有絬介性の大小によって大きく文配されるこ

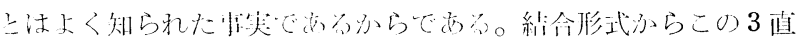

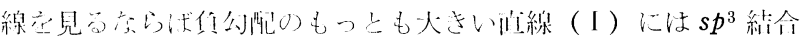

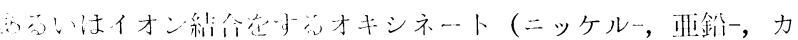
ドミウムー，マグネシウムー，カルシウムーオキシネート），㨁線

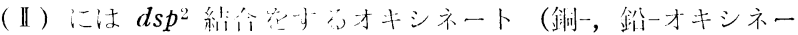

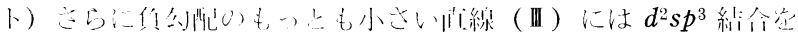

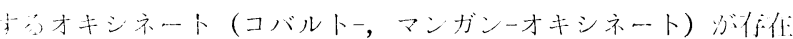

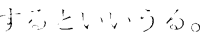

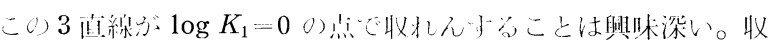

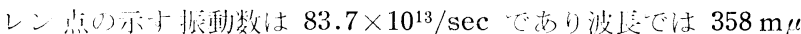

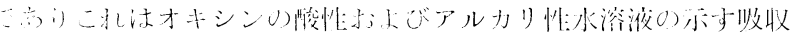

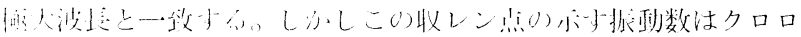

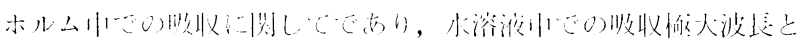

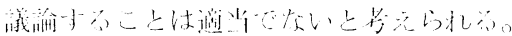

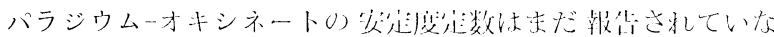

いが，パラジウムーオキシネートはクロロホルム溶液中で 平面構

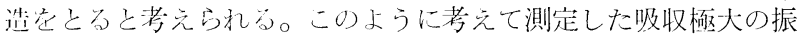
動数 $69.44 \times 10^{13} / \mathrm{sec}$ 少ら安定度定数索求的れば $\log K_{1}=16.80$ であるうと推测される。この值は銅ーオキシネートの值にくらべ て非常に大きいが，パラジウムーオキシネートが弱塩酸陵性でも キレートをつくえことを考えれば尒想外ではないと考えられる。 また酸性溶液に扎けるオキシン，一なわち（II）の構造がク口ロ ホルム中で存在吘台ならば吸収は $378 \mathrm{~m} \mu\left(79.35 \times 10^{13} / \mathrm{sec}\right)$ に あると考えられる。

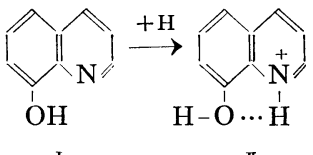

金属キレート生成法配位子より金属に電子妿与兄られて結合与

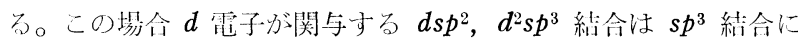

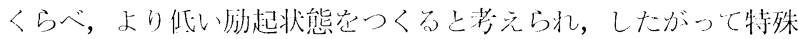

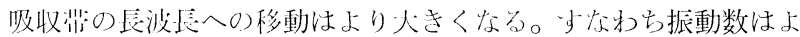
り小さくなとと若えられる。ニッケルーオキシネートは水溶液中

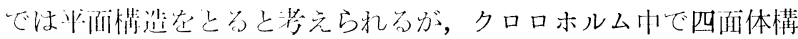

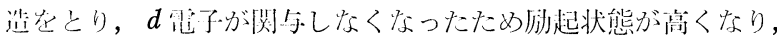
したがって比較的短波唇に吸収極大が出るのであるう。それに対 してマンガンーオキシネートは水溶液中での生成定数は小さいが

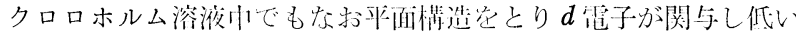
励起状態安つくり，そのため比較的長波脣に收収極大を有寸るの でるう。

本研究学行なうにあたり御指導をたまわった京都大学理学部不 橋雅義教授扎よび神门大学理学部土橋正二教授に㳭㴬する。

（明和 34 年４月，日本化学会第 12 年会（一部）講演）

\title{
臭化水素酸によるビスマスの紫外分光光度定量法
}

\author{
( 胉和 34 作 3 月 23 日受理)
}

川本而麓们

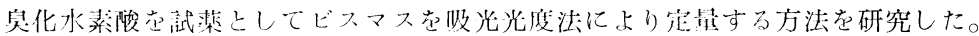

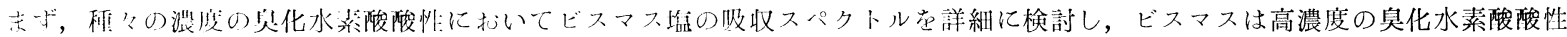

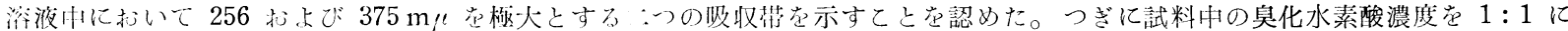

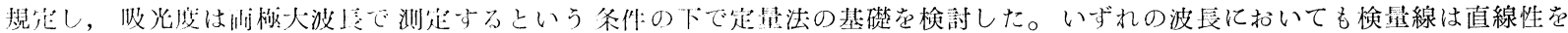
亦し，その方问係数は $256 \mathrm{~m} \mu$ では $0.2248,375 \mathrm{~m} \mu$ では 0.0839 であり，财光度の温度係数それぞれ $0.0008 /{ }^{\circ} \mathrm{C}(375 \mathrm{~m} \mu)$ ， $0.0022(256 \mathrm{~m} / !) / 0 \mathrm{C}$ であった。鉄，羟，スズ扎上びアンチモン等が奴害する。本法の特長としては，操作が簡便であり，感度が

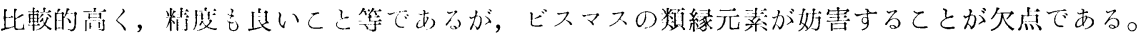

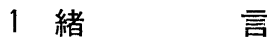

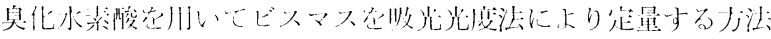

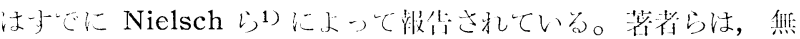

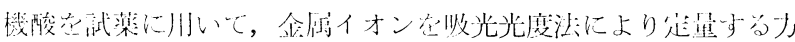

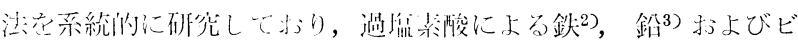

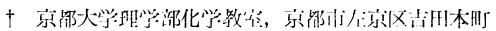

1) W. Nielsch, G. Böltz, Anal. Chim. Acta 11, 438 (1954).

2) M. Ishibashi, T. Shigematsu, Y. Yamamoto, M. Tabushi, T. Kitagawa, Bull. Chem. Soc. Japan 29, 57 (1956).
スマス ${ }^{4}$ ，硫酸による鉄5)掞よびビスマス ${ }^{6}$ ，程酸による鉄7およ び具化水素酸による鉛㝵等についてすでに報告してきた。

この拨告は臭化水素酸を用いてビスマスを定量する方法を検討 したものである。まず，種々浱度の臭化水素酸酸性溶液における

3) 石橋, 山本, 日色, 分析化学 7, 582 (1958)

4) 山本, 分析化学 8，8 9 号化揭載予定.

5）石棌, 重松,山本，田伏，北川，日化 76，758 (1956).

6）山本，日化投稿中。

7) M. Ishibashi, T. Shigematsu, Y. Yamamoto, M. Tabushi, T. Kitagawa, Bull. Chem. Soc. Japan 30, 343 (1957).

8）山本，日化投稿中. 
ビスマス塩の紫外部における吸収スペクトルを詳紻に測定したの ち，臭化水素酸它瓶薬としてビスマスイオン花吸光光度等量する

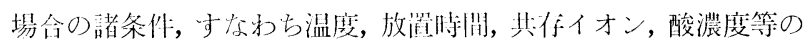

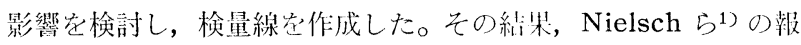

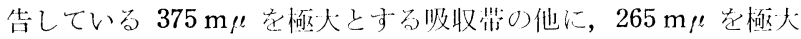

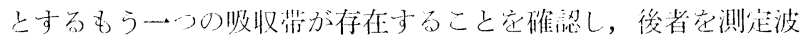
長と寸れ代さらによい感度でビスマスを等量しうること，酸源度 の增大とともに吸收带は長波長側一移動するが，約 $2.6 \mathrm{~N}$ 以上の 臭化水素酸浱度では両吸収带の極大波長は移動しないしとなどが わかったので報告する次第である。

\section{2 実}

\section{1 装}

收收スペクトルの测定装简としては Beckman DU 型光热分 光光度計在使肞し，光源は水素放電管，吸收セルは光路辰 $1 \mathrm{~cm}$ の不英製のもの在それぞれ小いた。

\section{2 試 薬}

ビスマスの標準溶液はつぎのようにして調製した。

メルタ社製分析用炅純金属ビスマスの $0.5000 \mathrm{~g}$ 空科取し，約 $6 \mathrm{~N}$ の純硝酸安用いて溶解したのち，純過㘁素酸（1:1）の適量

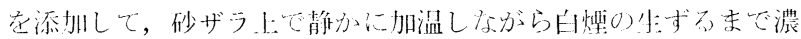

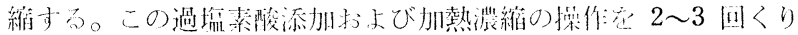

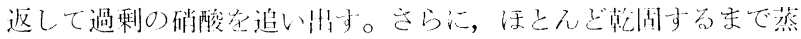

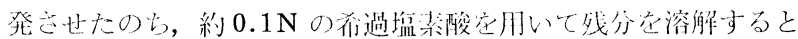
ともに西觀に $500 \mathrm{ml}$ に杀釈与る。

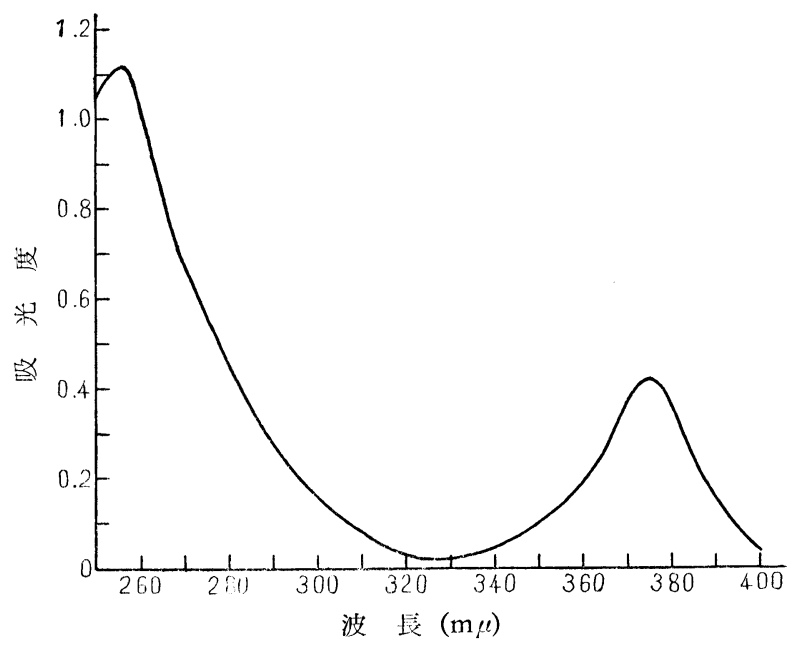

$\mathrm{Bi}^{3+} 5 \mathrm{ppm}, \operatorname{HBr}(1: 1)$, 対照; $\operatorname{HBr}(1: 1)$

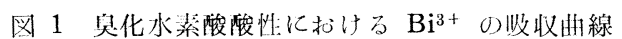

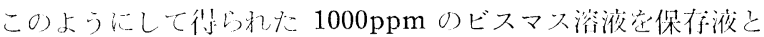

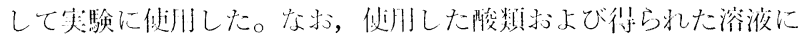

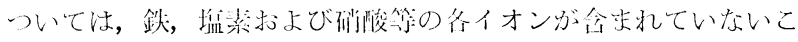
と忩確かわた。

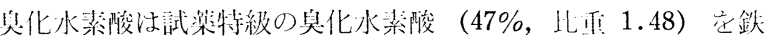

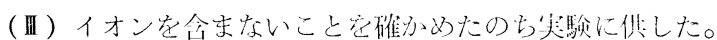

その他の狱薬類もできるだけ最紂のもの在俌川した。

\section{3 吸光度測定}

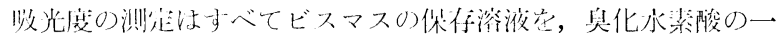

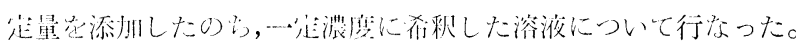

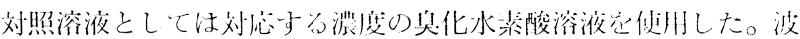

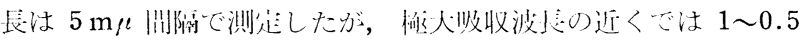
$\mathrm{m}$ ルごとに测定した。

\section{3 結 果}

\section{1 吸収スペクトル}

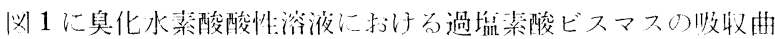

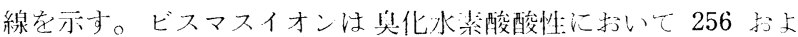
び $375 \mathrm{~m} / \ell$ 起極大とする二つの收收带定示している。さりに，種

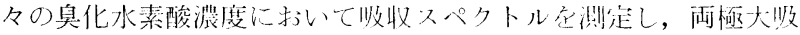

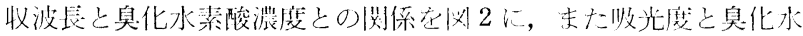

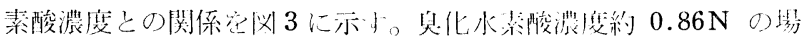

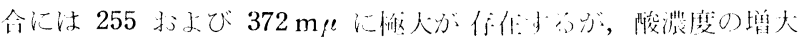

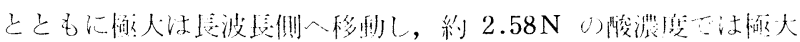

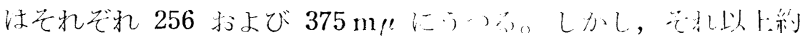

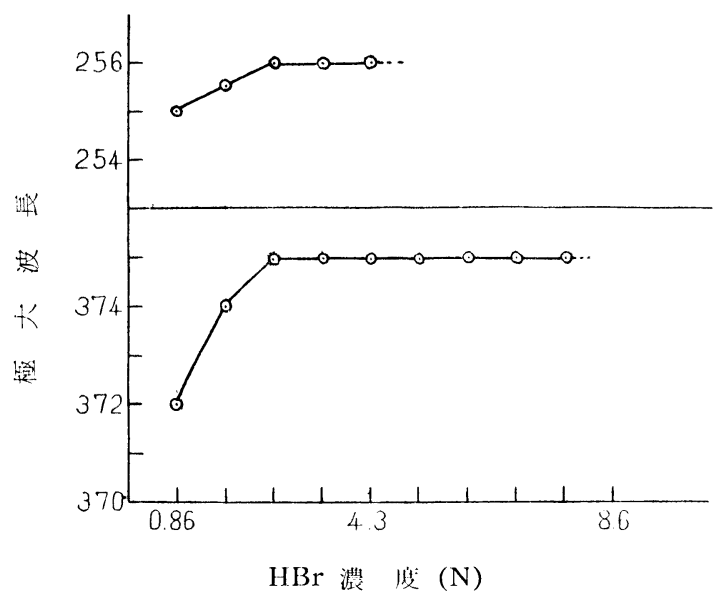

$\mathrm{Bi}^{3+}$ 5ppm, $\operatorname{HBr}(1: 1)$, 対览; $\operatorname{HBr}(1: 1)$

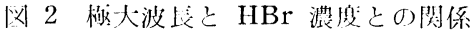

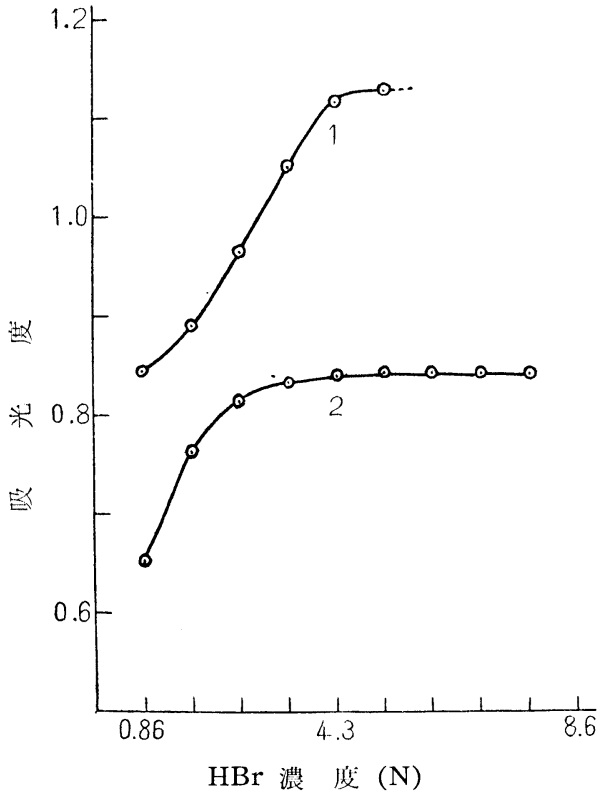

1: $\mathrm{Bi}^{3+} 5 \mathrm{ppm}, \mathrm{HBr}(1: 1)$, 対照; $\operatorname{HBr}(1: 1)$

2: $\mathrm{Bi}^{3+} 10 \mathrm{ppm}, \operatorname{HBr}(1: 1)$, 対笴; $\operatorname{HBr}(1: 1)$ 図 3 吸光度々 $\mathrm{HBr}$ 濃废乞の阅係 


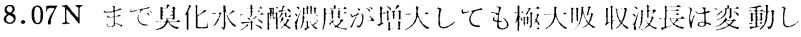

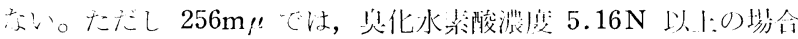

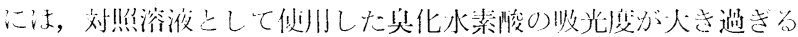

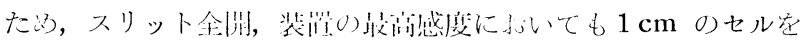

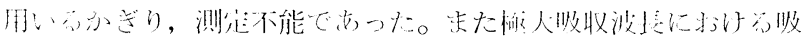

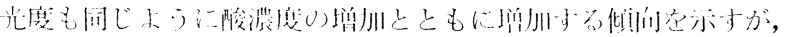

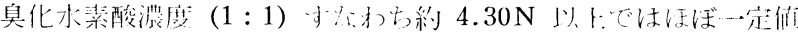

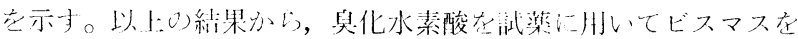

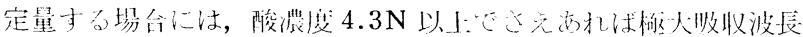

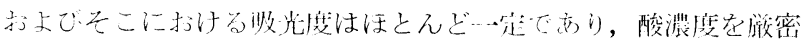

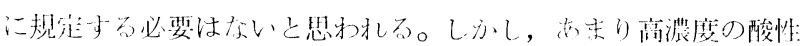

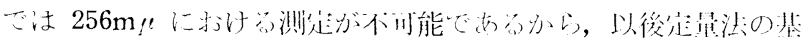

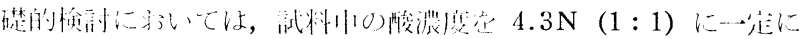

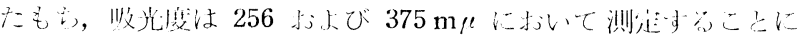
した。

\section{2 検量線}

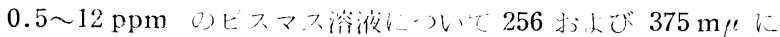

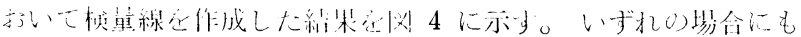

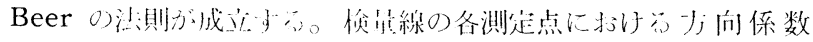

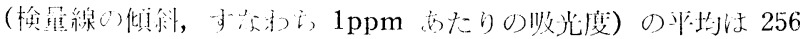

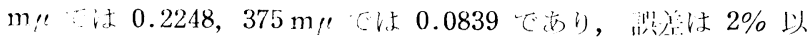
トア市つた。

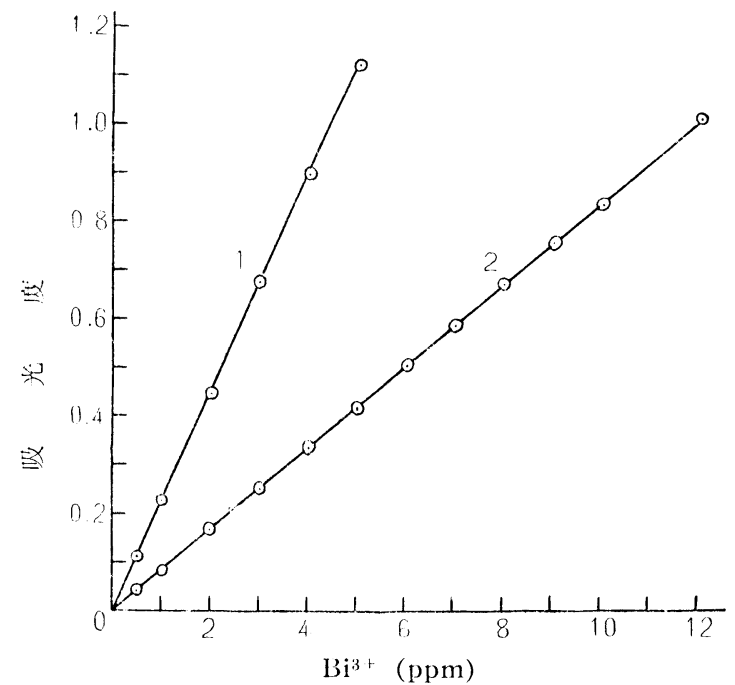

1: 波占 $256 \mathrm{~m} / \ell, \operatorname{HBr}(1: 1)$, 刘览; $\operatorname{HBr}(1: 1)$

2: 波 $1: 375 \mathrm{~m} \mu, \operatorname{HBr}(1: 1)$, 刘贤; $\operatorname{HBr}(1: 1)$

㣼 4 悗 線

\section{3 放置時閶の影響}

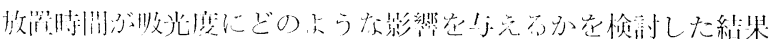

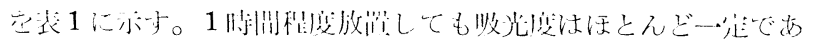

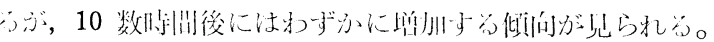

\section{4 温度の影響}

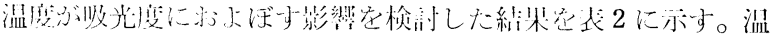

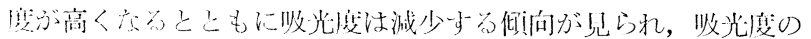
温度係数沬それでれ，0.0008/ ${ }^{\circ} \mathrm{C}(375 \mathrm{~m} \ell) ， 0.0022(256 \mathrm{~m} \mu)$ で (引つた。

\section{5 共存イオンの影響}

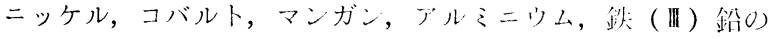

琵 1 放置時間の影響

$\mathrm{Bi}^{3+} 5.0 \mathrm{ppm}, \mathrm{HBr}(1: 1)$, 対照 $\mathrm{HBr}(1: 1)$ 放诲時間

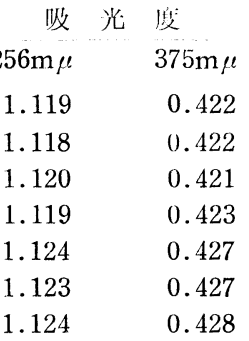

表 2 温度の影響

$\mathrm{Bi}^{3+} 5.0 \mathrm{ppm}, \operatorname{HBr}(1: 1)$, 刘照 $\mathrm{HBr}(1: 1)$

\begin{tabular}{|c|c|c|c|}
\hline 泾 & $\begin{array}{l}\text { 收光度 } \\
(256 \mathrm{~m} / \text { ) }\end{array}$ & $\begin{array}{c}\text { 满 } \\
\left({ }^{\circ} \mathrm{C}^{\text {度 }}\right.\end{array}$ & $\begin{array}{l}\text { 收光度 } \\
(375 \mathrm{~m} \mu)\end{array}$ \\
\hline 27 & 1.096 & 31 & 0.398 \\
\hline 21 & 1.110 & 25 & 0.410 \\
\hline 19 & 1.114 & 20 & 0.418 \\
\hline 17 & 1.118 & 18 & 0.420 \\
\hline 13 & 1.127 & 13 & 0.423 \\
\hline
\end{tabular}

表 3 共存イオンの影響

$\mathrm{Bi}^{3+} ; 5.0 \mathrm{ppm}, \operatorname{HBr}(1: 1)$, 対照 $\mathrm{HBr}(1: 1)$

$\begin{array}{lccr}\text { 基存イオン } & \begin{array}{c}\text { 共存是 } \\ (\mathrm{ppm})\end{array} & 256 \mathrm{~m} \mu & \text { 光 } \\ & & 1.118 & 0.420 \\ - & 100 & 1.118 & 0.420 \\ \mathrm{Co}^{2+} & 100 & 1.119 & 0.421 \\ \mathrm{Mn}^{2+} & 100 & 1.119 & 0.420 \\ \mathrm{Ni}^{2+} & 10 & 1.448 & 0.493 \\ \mathrm{~Pb}^{2+} & 100 & 1.118 & 0.420 \\ \mathrm{Al}^{3+} & 10 & >2 & 0.620 \\ \mathrm{Fe}^{3+} & 10 & 1.718 & 0.432 \\ \mathrm{Sn}^{4+} & 10 & >2 & 1.862 \\ \mathrm{Sb}^{5+} & 10 & 1.119 & 0.420 \\ \mathrm{As}^{5+} & & & \end{array}$

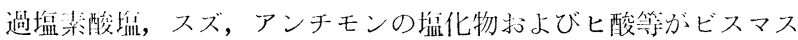

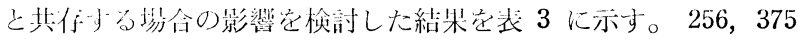
$\mathrm{m} \mu$ U恻波埝に执いて，ニッケル，コバルト，マンガン，アルミ

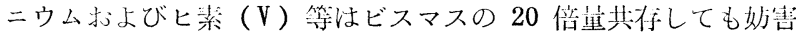
しないが，鉄，鉛，スズ拈よびアンチモン等はいずれも此呮差を 与え，とくにアンチモンの影響はいちじるしい。

\section{4 考察}

\section{1 吸収スペクトル}

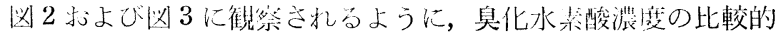
低い啰公の收收スベクトルひ变動は， $[\mathrm{BiBr}]^{2+},\left[\mathrm{BiBr}_{2}\right]^{+}$,

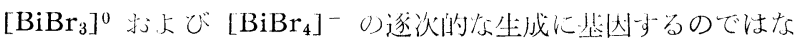

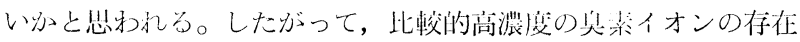

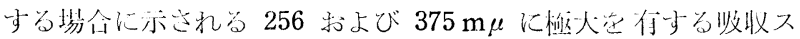

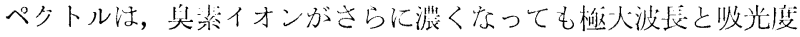

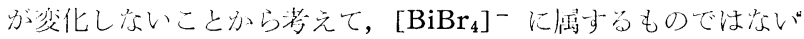

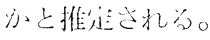

\section{2 定量法}

Nielsch らの川川いた $375 \mathrm{~m} \mu$ よりも，256 $\mathrm{m} \mu$ を测定波長とし

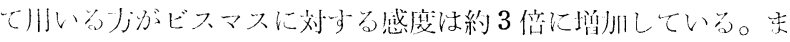
た，ビスマスに刘して最も一般に沏いられているジチゾン法と此 
較するならば，操作がきわわて簡単であり，系の吸光底は恔似

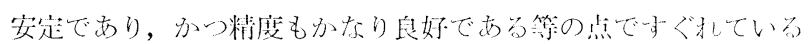

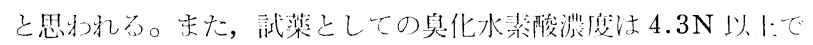

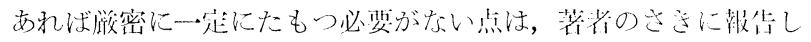

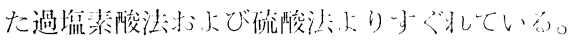

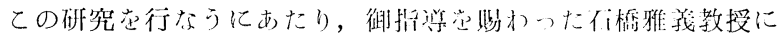
深く感謝与る。

\section{ペーパークロマトグラフィーの研究 $(\text { 第 } 3 \text { 報 })^{1)}$ \\ 無機物水溶液を展開剤としてヒ素，アンチモン，スズの分離}

(昭和 34 年: 3 月 23 日受理)

今 井弘

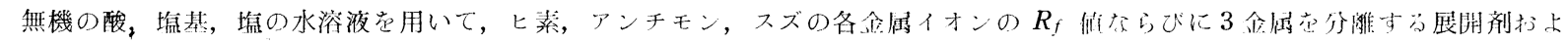
び認知可能範明苍調ベた。

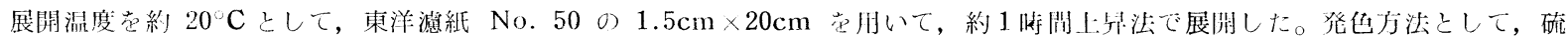

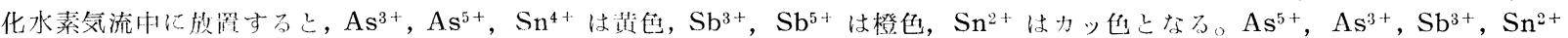

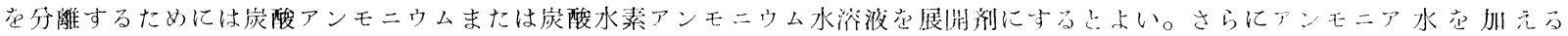

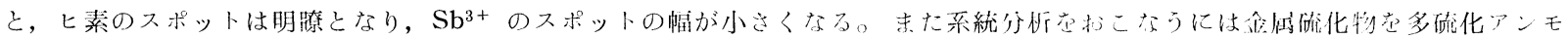

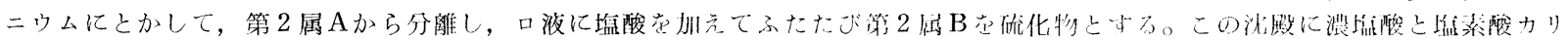

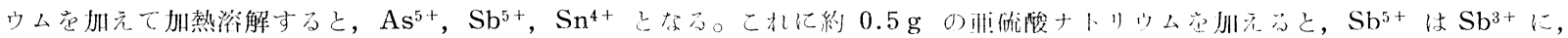

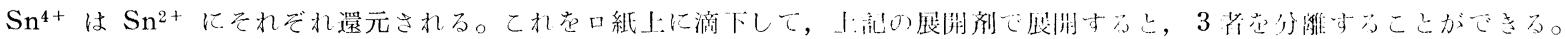

\section{1 緒論}

前報1で第 2 属 $\mathrm{A}$ の水銀, 鉛, 銅, ビスマス, カドミウム在一次恨 開法で分離したが，本報では第２属 $\mathrm{B} の$ ヒ素，アンチモン，スズ の分離定調べた。有機溶媒艺展閁剂として，ヒ秦2，アンチモンろ

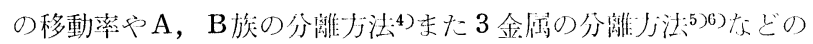

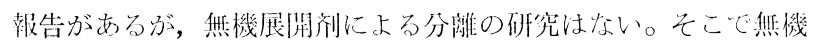
の陵，塯基，嫶の水溶液で展開剂をつくり，各金属イオンの移動

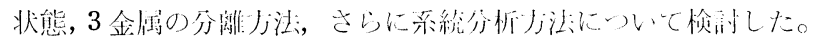

\section{2 試料調製，実験方法}

金属塩ならびにその湍麻はつぎのようにした。

\section{1 七 素}

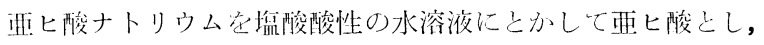
ヒ酸はただセに水にとが。

\section{2 アンチモン}

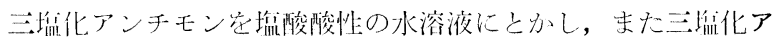

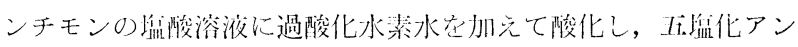
チモン管つくった。

\section{3 ス ズ}

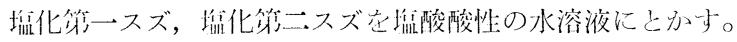

以上の上うにしてつくった㷪の金属イオン湡废は，とれぞれ $30 \gamma / 3 \times 10^{-3} \mathrm{cc}$ になるようにした。笑験方法法約 $20^{\circ} \mathrm{C}$ で, 米洋

†閶西大学工学部, 大阪门大淀区

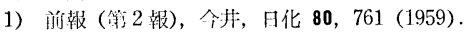

2) 原㳄，坂本，日化 73，611 (1952).

3) M. Lederer, Anal. Chim. Acta 2, 261 (1948).

4) M. Lederer, ibid. 3, 476 (1949).

5) 原㳄，日化 72, 423 (1951).

6) F. H. Bursta1l, G. R. Davies, R. P. Linstead, R. A. Wells, J. Chem. Soc. 1950, 516 .

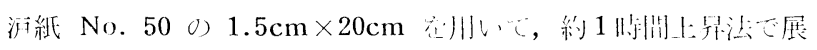

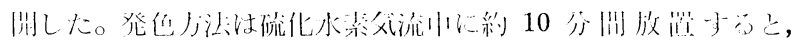

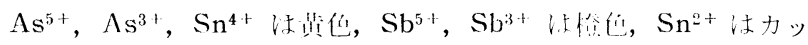
(ii)

\section{3 実験結果および考察}

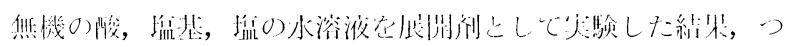
ざひようになった。

\section{1 酸水溶液による展開}

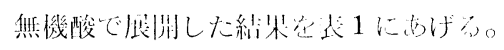

$$
\text { 发 } 1
$$

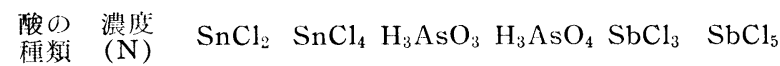

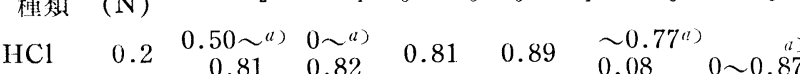

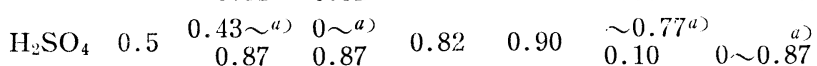
$\begin{array}{llllllll}\mathrm{HNO}_{3} & 0.5 & 0.42 \sim^{(a)} & \left.0 \sim^{a}\right) & 0.84 & 0.88 & \sim 0.71^{(a)} & (a)\end{array}$ $\begin{array}{lllllllll}\mathrm{H}_{3} \mathrm{PO}_{4} & 0.5 & 0.83 & 0.90 & 0.86 & 0.92 & 0.08 & 0.92\end{array}$

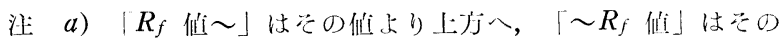

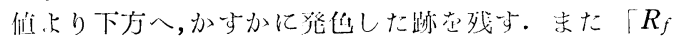

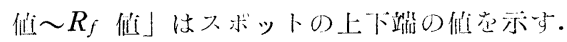

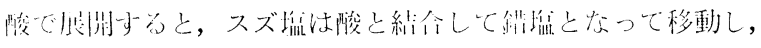

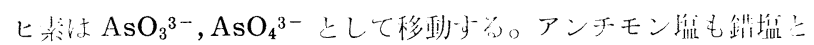

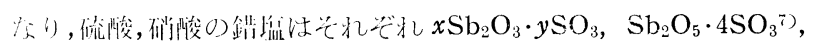

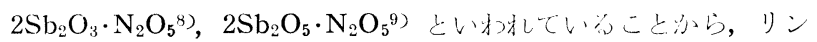

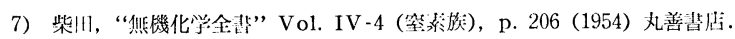

8) E. Péligot, Ann. Chim. Phys. 20, 283 (1847).

9) V. Thomas, Compt. Rend. 120, 1116 (1895). 